\title{
The Neurotrophin Receptor p75 Binds Neurotrophin-3 on Sympathetic Neurons with High Affinity and Specificity
}

\author{
Georg Dechant, ${ }^{1}$ Pantelis Tsoulfas, ${ }^{2}$ Luis F. Parada, ${ }^{3}$ and Yves-Alain Barde ${ }^{1}$ \\ ${ }_{1}^{1}$ Max-Planck-Institute for Psychiatry, Department of Neurobiochemistry, 82152 Planegg-Martinsried, Germany, \\ 2Department of Neurological Surgery and the Miami Project, University of Miami, School of Medicine, Miami, Florida \\ 33136, and ${ }^{3}$ Center for Developmental Biology, University of Texas Southwestern Medical Center, \\ Dallas, Texas 75235-9133
}

\begin{abstract}
High-affinity neurotrophin-3 (NT3) receptors have been identified on nerve growth factor (NGF)-dependent sympathetic neurons, but their occupancy by NT3 does not lead to neuronal survival. The molecular nature of these NT3 binding sites was investigated in this study. With freshly dissociated embryonic day 11 (E11) chick sympathetic neurons, cross-linking experiments revealed that the main receptor responsible for highaffinity specific binding was the neurotrophin receptor p75 (p75 NTR), with only a small fraction corresponding to trkC. When E11 sympathetic neurons were cultured in the presence
\end{abstract}

of NGF, trkC transcripts became undetectable, but high-affinity specific NT3 binding persisted. Cross-linking and antibody inhibition experiments indicated that p $75^{\mathrm{NTR}}$ was the only detectable NT3 receptor protein. These characteristics were not observed when p $75^{\mathrm{NTR}}$ was expressed in transformed cells. We conclude that p $75^{\mathrm{NTR}}$ can exist in neurons in a confirmation conferring hitherto unrecognized properties to this receptor.

Key words: neurotrophins; neurotrophin receptors; sympathetic neurons; neurotrophin-3; $75^{\text {NTR }}$; trkC
Neurotrophin-3 (NT3) shows a unique pattern of receptor interactions, because it binds to all identified neurotrophin receptors. Like all neurotrophins, NT3 interacts with the $\mathrm{p} 75^{\mathrm{NTR}}$ receptor, but it also binds and activates the receptor tyrosine kinases trkA, trkB, and trkC. In vivo, binding of NT3 to trkC is clearly of relevance, because there are striking similarities in the phenotypes of NT3 (-/-) and trkC (-/-) mice (for review, see Snider, 1994; Lewin and Barde, 1996). With regard to neuronal survival, however, the loss of trkC function is less dramatic than that of NT3, and detailed analyses with neurons isolated from trk (-/-) mice have revealed that in the absence of trkC, NT3 uses trkA and trkB instead (Davies et al., 1995). Although remarkably useful for examining the in vivo relevance of neurotrophin receptor genes, such studies do not define the various molecular components participating in neurotrophin binding at the surface of neurons. In vitro studies, notably with PC12 cells, have helped to define the molecular nature of high-affinity specific NGF binding sites (Chao et al., 1986; Radeke et al., 1987; Hempstead et al., 1991). These studies led to the conclusion that $\mathrm{p} 75^{\mathrm{NTR}}$, expressed at suitable levels, increases the ability of the NGF receptor trkA to detect low concentrations of NGF (Benedetti et al., 1993; Barker and Shooter, 1994) and confers increased specificity of NGF binding for trkA (Davies et al., 1993; Lee et al., 1994). With regard to neurotrophins other than NGF, only a few studies to date have examined the molecular nature of neurotrophin binding sites on neurons. With BDNF and NT3, previous cross-

Received Feb. 21, 1997; revised April 16, 1997; accepted April 25, 1997.

We thank Dr. Alfredo Rodríguez-Tébar for advice concerning the cross-linking experiments and Tatjana Freudenreich for excellent technical assistance. We are grateful to Drs. Weskamp and Reichardt for providing antibodies and to Genentech for the gift of neurotrophins.

Correspondence should be addressed to G. Dechant, Max-Planck-Institute for Psychiatry, Department of Neurobiochemistry, 82152 Planegg-Martinsried, Germany.

Copyright (C) 1997 Society for Neuroscience $0270-6474 / 97 / 175281-07 \$ 05.00 / 0$ linking experiments have identified trkB and trkC as components of high-affinity receptors on embryonic neurons (Escandón et al., 1993; Rodríguez-Tébar et al., 1993; Escandón et al., 1994), but the participation of $\mathrm{p} 75$ in the formation of such sites, if any, remains unclear.

The chick sympathetic neurons are one population of neurons that are amenable to receptor composition analyses. Like dissociated chick retinal cells, used previously for similar purposes (Rodríguez-Tébar et al., 1993), they can be isolated in sufficient numbers. Sympathetic neurons can be studied both after acute dissociation and in cell culture after they have formed long processes. This is of interest, because in vivo, neurotrophins are more likely to encounter neurotrophin receptors on processes than on cell bodies. In a previous study, high-affinity specific NT3 binding sites were described on embryonic day 11 (E11) sympathetic neurons (Dechant et al., 1993b). Such sites can usually be correlated with neuronal survival, but such was not the case with these neurons. The same neurons co-express high-affinity sites for NGF, and occupancy of the latter led to neuronal survival, indicating that all the components necessary to link tyrosine kinases with the prevention of cell death machinery were functional in these neurons (Dechant et al., 1993b). The results presented here unexpectedly reveal that the main component for NT3 highaffinity specific binding on sympathetic neurons and their processes can be accounted for by $\mathrm{p} 75$.

\section{MATERIALS AND METHODS}

Reverse transcription-coupled PCR. Total RNA was obtained from sympathetic ganglia and neuronal cell cultures, with use of the RNEasy kit (Qiagen, Hilden, Germany), and treated with DNase. One microgram of total RNA was reverse-transcribed with $0.5 \mu \mathrm{g}$ of oligo-dT ${ }_{12-18}$ (Pharmacia, Piscataway, NJ) and Superscript II Reverse Transcriptase (Life Sciences, Hialeah, FL) for $1 \mathrm{hr}$ at $45^{\circ} \mathrm{C}$. Transcripts of 30-60 ng total RNA were amplified $\left(94^{\circ}, 62^{\circ}, 72^{\circ} \mathrm{C}, 30 \mathrm{~min}\right.$ each) with $0.1 \mu \mathrm{M}$ primer (see below), $0.33 \mathrm{~mm}$ dNTP (Pharmacia), and $0.4 \mu \mathrm{l}$ (2 U) Ampli-Taq (Perkin-Elmer, Emeryville, CA) in a total volume of $60 \mu$ l. SYBR Green 
(Biomol, Plymouth Meeting, PA) stained amplificates were analyzed by $1 \%$ agarose gel electrophoresis. $T r k C$ amplificates were transferred onto Hybond $\mathrm{N}$ membrane (Amersham-Buchler, Braunschweig, Germany) and hybridized against a ${ }^{32} \mathrm{P}$-labeled trkC-specific cDNA probe. The linear range of the amplification reactions was determined for all primer combinations. Chick glyceraldehyde 3-phosphate dehydrogenase (GAPDH) transcripts were amplified for $18-20$ cycles with the primers 5'-TGGGAAGCTTACTGGAATGGC-3' and 5'-GCAGGATGCAGAACTGAGCG-3', chick $t r k C$ full-length and kinase truncation transcripts (Garner and Large, 1994) for 24-26 cycles with 5'AGCCCCACCAATGACAAAATGC-3' and 5'-CTCCCAGAGGATCACCCCG-3', chick trkC kinase deletion transcripts (Garner and Large, 1994) for 34-36 cycles with 5'-CCAATAAGCCTCCCTGGACATTCC-3' and 5'-CCCTGTTATCTGGTGACAGAAAACC-3', and chick p75 (Large et al., 1989) for 31-33 cycles with $5^{\prime}$ CCTGCCTGGACAGTGTGAC-C-3' and 5'-TCTGCCAGGGTGGTGGCC-3'. Amplified trkC fragments were isolated from agarose gels and sequenced with the amplification primers on a sequencing automate (Applied Biosystems 373A; Applied Biosystems, Foster City, CA).

Neurotrophins and antibodies. Recombinant mouse NT3 and BDNF produced in a Vaccinia virus-based expression system were used for iodination (Götz et al., 1992). Chinese Hamster Ovary (CHO)-derived human recombinant protein was used for radiolabeling of NGF. For biological assays and inhibition of binding, neurotrophins from the following sources were used: mouse NGF from salivary glands of adult male mice (purified according to Suda et al., 1978), recombinant human NGF (Genentech, San Francisco, CA), Vaccinia-derived mouse recombinant $\mathrm{BDNF}$, human recombinant BDNF expressed in $\mathrm{CHO}$ cells (Genentech), Vaccinia-derived mouse recombinant NT3, and human recombinant NT4/5 (CHO, Genentech). The rabbit polyclonal serum (Chex) directed against the extracellular domain of chick p $75^{\text {NTR }}$ was a gift from Drs. Weskamp and Reichardt.

Preparation of neurons. Fertilized chicken eggs were obtained from various commercial sources. For the preparation of sympathetic chains, embryos were staged according to Hamburger and Hamilton (1951) and E11 (stage 37/38) animals were removed from the egg, washed in PBS, and dissected under a stereomicroscope. Paravertebral sympathetic chains were taken from the thoracolumbar portion of the embryos, freed from connective tissue, and collected in ice-cold PBS. The chains were treated with $0.1 \%$ trypsin (Worthington, Freehold, NJ) at $37^{\circ} \mathrm{C}$ in $\mathrm{PBS}$ for 15-20 min. The ganglia were washed once in PBS and resuspended in Ham's F14 (Life Sciences) supplemented with 10\% horse serum (Boehringer Mannheim) and 5\% fetal calf serum (Life Sciences). Chains were dissociated by gentle trituration in a siliconized Pasteur pipette. The cell suspension was then filtered through a $40 \mu \mathrm{m}$ nylon mesh (Falcon) and incubated on plastic cell culture dishes (Nunc, Dannstadt, Germany) for $2 \mathrm{hr}$ in an incubator at $37^{\circ} \mathrm{C}$ in a $3 \% \mathrm{CO}_{2}$ atmosphere. During this preplating period non-neuronal cells settle onto the plastic dish, whereas neurons attach only loosely. The cell suspension, containing $>95 \%$ neurons, was collected by aspiration, and the number of cells was counted in a hemocytometer. For binding or cross-linking experiments, cells were centrifuged $(200 \times g, 5 \mathrm{~min})$ and resuspended in ice-cold $\mathrm{Ca}^{2+} / \mathrm{Mg}^{2+}$ free Krebs-Ringer's solution-HEPES buffer (KRH) containing $5 \mathrm{mg} / \mathrm{ml}$ BSA (Sigma, St. Louis, MO) and $0.1 \mathrm{mg} / \mathrm{ml}$ horse heart cytochrome $c$ (binding buffer; Serva Feinbiochemica, Heidelberg, Germany).

Cell culture. Dissociated neurons were plated on dishes previously coated with poly-DL-ornithine (Sigma) and RN22 conditioned medium (Palm and Furcht, 1983) and incubated in a $3 \% \mathrm{CO}_{2}$ atmosphere at $37^{\circ} \mathrm{C}$ (Dechant et al., 1993b). For binding studies and cross-linking experiments on cell culture dishes, neurons were plated at a density of 3-10 $\times$ $10^{4}$ cells $/ 3 \mathrm{~cm}$ dish (Falcon) or $3.5-5.0 \times 10^{5}$ cells $/ 6 \mathrm{~cm}$ dish (Nunc). Mouse L-cells overexpressing the rat $p 75^{\text {NTR }}$ gene (PCNA cells) (Radeke et al., 1987) were grown in DMEM containing $10 \%$ heatinactivated fetal calf serum at $5 \% \mathrm{CO}_{2}$. Cells were removed from the dishes by gentle treatment with $0.01 \%$ trypsin (Worthington) for $10 \mathrm{~min}$ at $37^{\circ} \mathrm{C}$. The reaction was stopped by the addition of fetal calf serum (Life Sciences). The cells were centrifuged $(200 \times g, 5 \mathrm{~min})$ and resuspended in ice-cold binding buffer.

Iodination of neurotrophins, binding studies, and cross-linking experiments. NGF, NT3, and BDNF were iodinated using lactoperoxidase and ${ }^{125}$ I (Amersham IMS30) as described previously (Rodríguez-Tébar et al., 1992; Dechant et al., 1993a). The specific radioactivity was 125-175 $\mathrm{cpm} / \mathrm{pg}$ neurotrophin, and radiolabeled material was used within 1 week after the reaction.
Binding experiments with neurons from freshly dissected ganglia were performed at $4^{\circ} \mathrm{C}$ in a shaking water bath. For separation of free and bound radioactivity, a centrifugation method was used as described (Dechant et al., 1993a). Inhibition of binding experiments was performed as described previously (Dechant et al., 1993a). Binding on dishes was performed according to Rodriguez-Tébar and Rohrer (1991). Of six culture dishes per experimental point, three were used for the determination of unspecific binding and three for the determination of total binding. Before the experiments, neuronal cultures were incubated for $2 \times 2 \mathrm{hr}$ in fresh serum-containing medium to deplete the neuronal neurotrophin receptors from ligand. Binding was performed at room temperature in $1.5 \mathrm{ml}$ binding buffer per dish. The dishes were gently agitated on a horizontal shaker (Cello Shaker, Renner). Dishes for the determination of unspecific binding were preincubated with $500 \mathrm{ng}$ of unlabeled NT3 for $15 \mathrm{~min}$. Antibodies were preincubated for $60 \mathrm{~min}$. Radiolabeled NT3 was then added for an additional $60 \mathrm{~min}$ to all plates. After the incubation, the supernatant was removed by aspiration, and the dishes were washed once with $2 \mathrm{ml}$ of KRH containing $1 \mathrm{mg} / \mathrm{ml} \mathrm{BSA}$ for $15 \mathrm{~min}$ and left to dry. The bound radioactivity was eluted in $1 \mathrm{ml}$ of $2 \%$ SDS solution and counted on a gamma counter with $>70 \%$ counting efficiency (Canberra Packard Cobra). Free radioactivity in all experiments was determined using $3 \times 10 \mu$ l binding solution from each experimental point. No significant depletion of free ligand was observed during the binding. Specific binding was determined by subtraction of unspecific binding from total binding, and data were analyzed using the Graphit software package (Erythacus Software London).

Incubations for cross-linking experiments were performed at $4^{\circ} \mathrm{C}$ in a water bath with freshly dissociated neurons $\left(5 \times 10^{5}-1 \times 10^{6}\right.$ cells in 1 $\mathrm{ml})$ or at room temperature with cell cultures as described above, with the modification that after the incubation with radioligand cross-linking reagents, either $10 \mathrm{~mm}$ 1-ethyl-3-[3-dimethylaminopropyl] carbodiimide hydrochloride (EDC) (Pierce, Rockford, IL) or $1 \mathrm{~mm}$ (bis [sulfosuccinimidyl] suberate $\left(\mathrm{BS}^{3}\right)$ (Pierce) was added for $30 \mathrm{~min}$. The reaction was quenched by the addition of $40 \mathrm{~mm}$ Tris/ $\mathrm{HCl}, \mathrm{pH} 8.0$, for $10 \mathrm{~min}$. Cell suspensions were centrifuged at $3000 \mathrm{rpm}$ for $1 \mathrm{~min}$, and the supernatant was aspirated. The pellets were washed once in ice-cold KRH containing protease inhibitors (aprotinin $10 \mu \mathrm{g} / \mathrm{ml}$, leupeptin $1 \mu \mathrm{g} / \mathrm{ml}$, PMSF $1 \mathrm{~mm}$ ) and lysed by boiling in $4 \times$ concentrated Laemmli gel loading solution containing $6 \% 2$-mercaptoethanol for $5 \mathrm{~min}$. Cell cultures were washed two times in KRH and lysed with $4 \times$ Laemmli solution on the culture dish. Lysates were centrifuged at $20,000 \times g$ for $20 \mathrm{~min}$, and aliquots of the supernatant containing equal amounts of protein were analyzed by $7.5 \%$ SDS-PAGE. The dried gels were exposed for 2-14 d to autoradiographic film (Kodak X-omat AR).

\section{RESULTS \\ $P 75^{\text {NTR }}$ and $t r k C$ gene expression in chick sympathetic neurons}

Several alternative transcripts of the $\operatorname{trk} C$ gene identified previously in embryonic chick brain (Fig. 1A) (Garner and Large, 1994) were amplified by RT-PCR from RNA isolated from E11 sympathetic ganglia (Fig. $1 B, C$ ). The use of a single set of tyrosine kinase specific primers resulted in the simultaneous amplification of two bands that were isolated and sequenced (Fig. $1 B)$. The larger DNA fragment encoded the expected fragment of the full-length, enzymatically active form of trkC. The smaller amplicon coded for an alternatively spliced variant of trkC with a truncation in the second half of the tyrosine kinase domain (Garner and Large, 1994). TrkC transcripts encoding tyrosine kinase insertion isoforms (data not shown) or isoforms with a deletion of the entire tyrosine kinase domain (Fig. 1C) are weakly expressed in sympathetic neurons. No evidence for differential expression of the kinase deletion, kinase truncation, and fulllength $t r k C$ transcripts was obtained between E7 and E11 (data not shown). The expression of trkC in freshly isolated ganglia was compared with neurons cultured in the presence of NGF for $5 \mathrm{~d}$ (Fig. 1C). All trkC transcripts were strongly downregulated in culture in comparison to $G A P D H$ or $p 75^{\mathrm{NTR}}$ gene expression (Fig. 1C). 

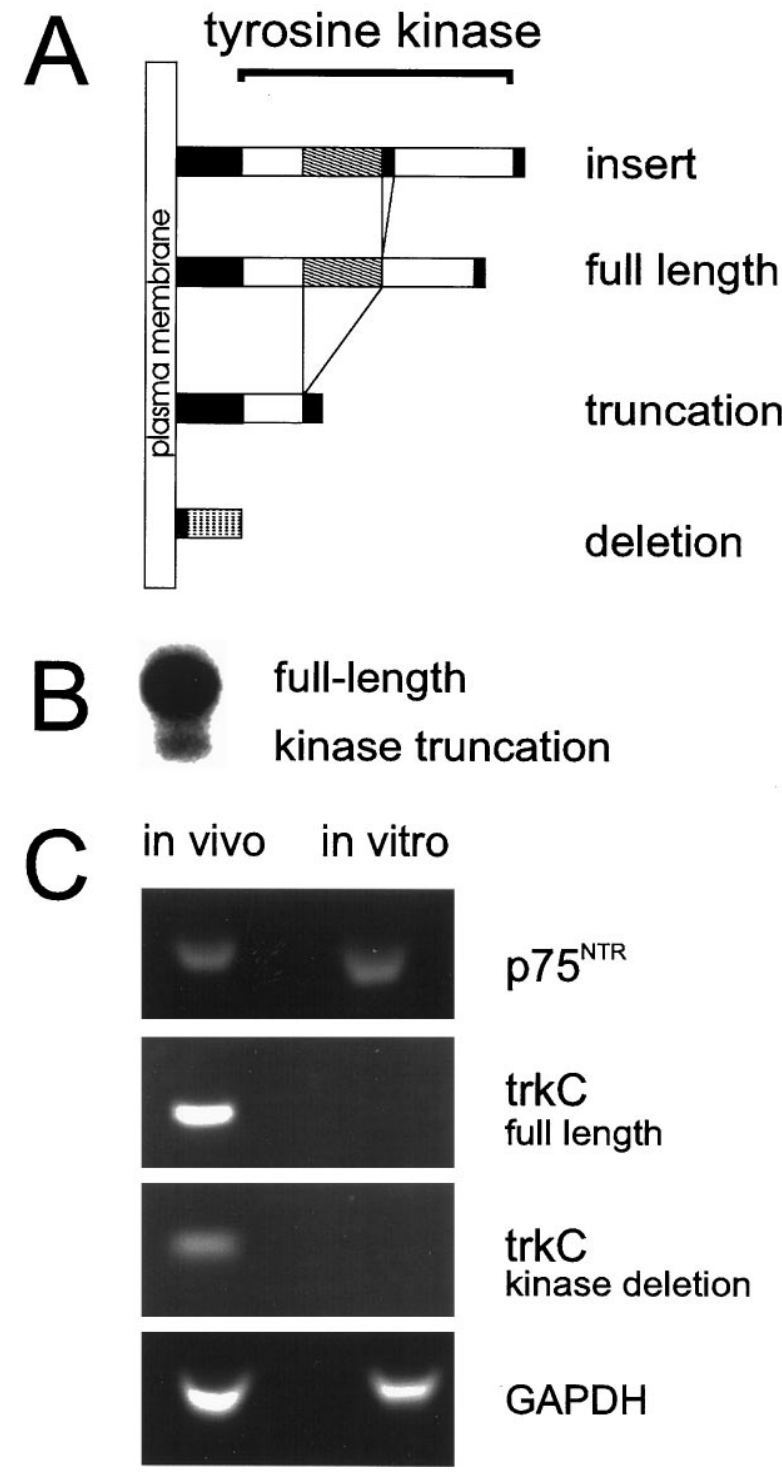

Figure 1. NT-3 receptor gene expression in sympathetic ganglia. $A$, Schematic representation of the protein isoforms encoded in $t r k C$ transcripts of chick sympathetic ganglia. At least four different $t r k C$ transcripts are generated by alternative splicing (Garner and Large, 1994) in sympathetic chick ganglia, of which the one encoding the enzymatically active full-length form is most abundant $(C) . B$, Sequences corresponding to the full-length receptor and an isoform with a truncation in the tyrosine kinase domain can be amplified simultaneously with primers flanking the deleted exon. The kinase truncation isoform is detectable by Southern blotting of the amplificate after 38 cycles when the reaction is already saturated for the full-length form. $C$, NT-3 receptor gene expression in sympathetic ganglia and neuronal cell cultures. cDNAs from embryonic stage 37/38 animals (Hamburger and Hamilton, 1951) were amplified with primers specific for the neurotrophin receptor genes $p 75^{\mathrm{NTR}}$ (31 cycles), trkC full length (26 cycles), or trkC kinase deletion (36 cycles) (Garner and Large, 1994). The kinase truncated variant $(B)$ and the kinase insertion form (data not shown) are present at very low abundance. The cDNA content of the samples was controlled by amplification of GAPDH (20 cycles). The expression of the trkC and $p 75^{\mathrm{NTR}}$ genes was compared in the sympathetic chains (in vivo) and in sympathetic neuronal cultures (in vitro, $5 \mathrm{~d}$ in the presence of $20 \mathrm{ng} / \mathrm{ml} \mathrm{NGF).} \mathrm{TrkC} \mathrm{but} \mathrm{not} p 75^{\mathrm{NTR}}$ transcripts were strongly downregulated in culture.

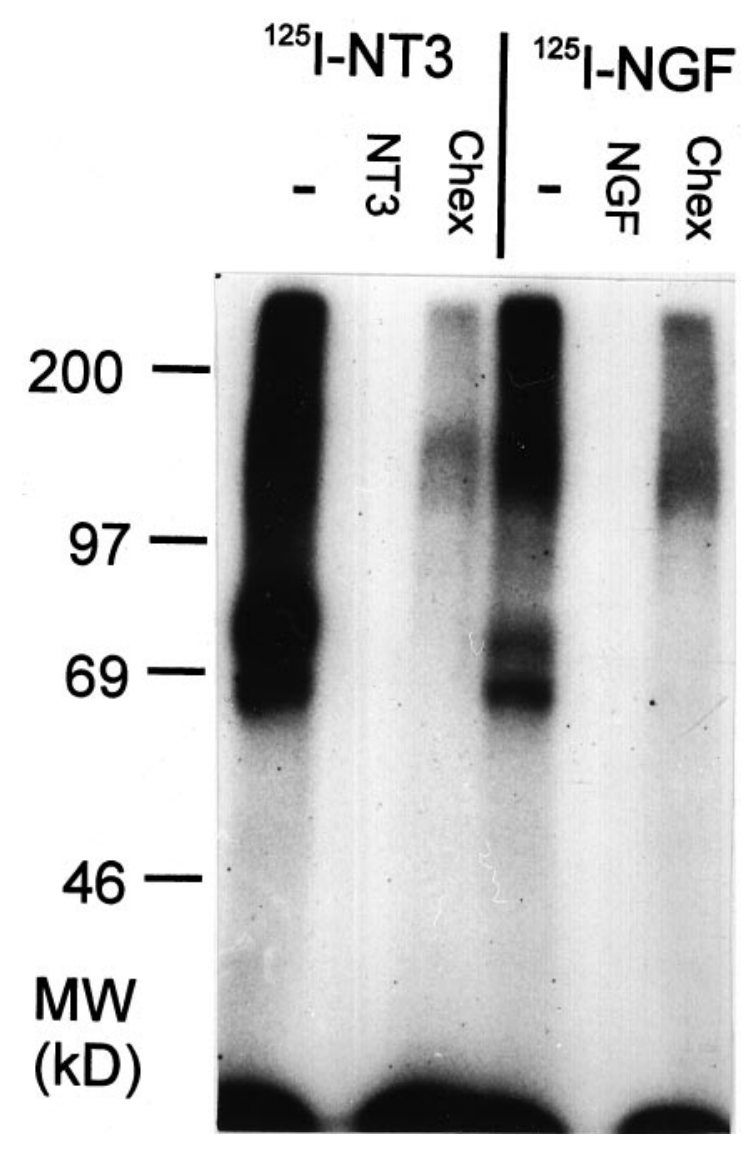

Figure 2. Cross-linking of NT3 and NGF to their receptors on sympathetic neurons. Cell suspensions of neurons freshly isolated from E11 chick embryos were incubated with radiolabeled NT3 or NGF at a concentration of $3 \times 10^{-11} \mathrm{M}(-)$, in the presence of a 130-fold excess of identical unlabeled factor, or with a 1:2000 dilution of an antiserum that prevents binding of neurotrophins to $\mathrm{p} 75^{\mathrm{NTR}}$ (Chex) (Weskamp and Reichardt, 1991). Proteins were chemically cross-linked with $\mathrm{BS}^{3}$ and neurotrophin receptor complexes identified by autoradiography of SDS polyacrylamide gels.

\section{NT3 receptors on the cell bodies of E11 sympathetic neurons}

Cell suspensions of neurons freshly isolated from E11 chick sympathetic ganglia were incubated with radiolabeled NT3 at $3 \times$ $10^{-11} \mathrm{M}$, a concentration preferentially filling high-affinity NT3 binding sites (Rodríguez-Tébar et al., 1992). After cross-linking with the bifunctional hydrophilic cross-linker $\mathrm{BS}^{3}$, the neurotrophin receptor complexes were analyzed by gel electrophoresis and autoradiography. Three bands were observed with apparent molecular masses of 60, 80, and $170 \mathrm{kDa}$ (Fig. 2). Binding was completely inhibited by the addition of a 130-fold molar excess of unlabeled NT3. The Chex anti-p75 ${ }^{\text {NTR }}$ antiserum (Weskamp and Reichardt, 1991) abolished binding to the 60 and $80 \mathrm{kDa}$ bands (Fig. 2). Both bands could also be precipitated with other antisera against $\mathrm{p} 75^{\mathrm{NTR}}$, confirming that $\mathrm{p} 75^{\mathrm{NTR}}$ is part of both complexes (data not shown). The $60 \mathrm{kDa}$ band is unlikely to result from proteolysis of the $80 \mathrm{kDa}$ monomer, because it is absent in material cross-linked with EDC from identical preparations (data not shown) but present when $\mathrm{BS}^{3}$ is used to cross-link NT3 to a cell line expressing p $75^{\text {NTR }}$ (see below). After incubation with Chex anti-p75 ${ }^{\text {NTR }}$ antiserum, a high molecular weight band persisted, and its size $(170 \mathrm{kDa})$ is consistent with the molecular mass expected for an NT3/trkC complex. This band was immu- 


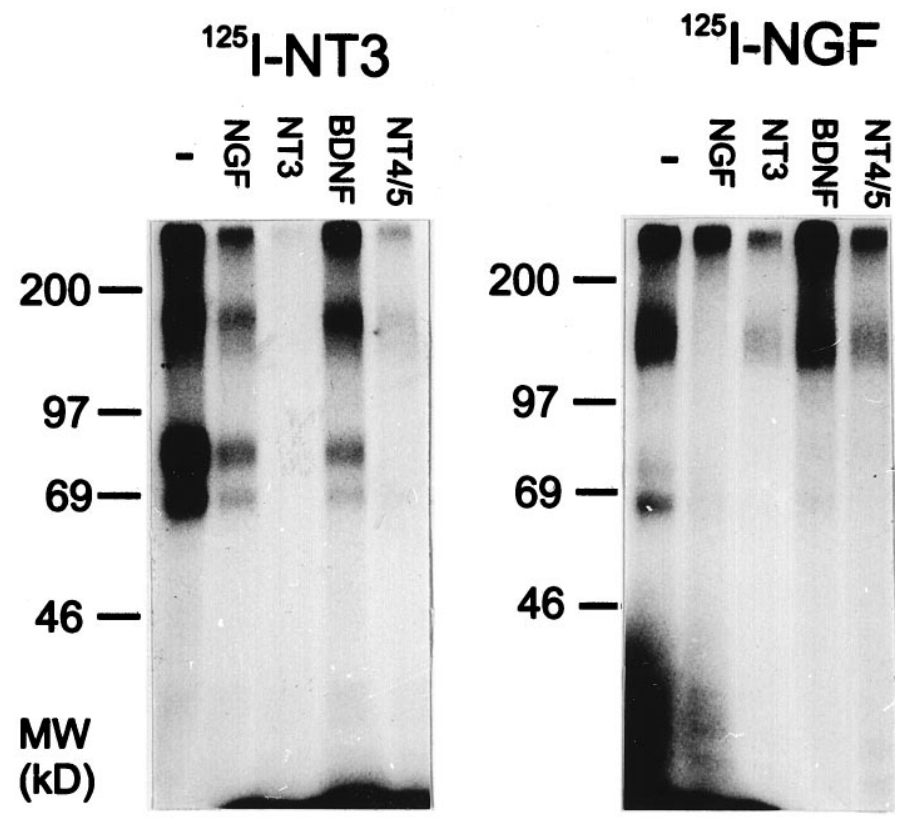

Figure 3. Ligand specificity of the NT3 and NGF receptors on E11 sympathetic neurons. Neuronal cell suspensions isolated from E11 sympathetic ganglia were incubated with $2 \times 10^{-11} \mathrm{M}$ radiolabeled NT3 or NGF alone (-) or in the presence of a 150 -fold excess of unlabeled neurotrophins NGF, NT3, BDNF, or NT4/5. Cross-linked receptorligand complexes were analyzed by SDS-PAGE followed by autoradiography of the dried gels.

noprecipitated with a pan-trk antiserum (Schröpel et al., 1995) (data not shown). Thus, both $\mathrm{p} 75^{\mathrm{NTR}}$ and full-length trkC are involved in NT3 high-affinity binding on freshly dissociated neurons. Similar results were obtained with NGF, although the NT3/ p $75^{\text {NTR }}$ complexes were more abundant than NGF/p $75^{\text {NTR }}$ under identical experimental conditions, independent of the use of $\mathrm{BS}^{3}$ (Fig. 2) or EDC as cross-linkers (data not shown). Also, the molecular weight of the NGF/trkA complexes (160 kDa) (Schröpel et al., 1995) is slightly lower than that of the NT3/trkC complex (Fig. 2). To test the ability of neurotrophins other than NT3 to compete with NT3 high-affinity binding, neurons freshly isolated from E11 sympathetic ganglia were incubated with $2 \times$ $10^{-11} \mathrm{M}$ radiolabeled NT3 in the presence of a $150 \times$ molar excess of unlabeled NGF, BDNF, and NT4/5. Analysis of the cross-linking products revealed that binding of radiolabeled NT3 to $\mathrm{p} 75^{\mathrm{NTR}}$ was only incompletely inhibited by NGF and BDNF at $3 \times 10^{-9}$ M (Fig. 3); however, human NT4/5 was essentially as effective as NT3 itself. In addition, binding of ${ }^{125}$ I-NT3 to trkC was markedly antagonized by NT4/5, but only slightly reduced by NGF and not significantly by BDNF. Parallel experiments with ${ }^{125} \mathrm{I}-\mathrm{NGF}$ indicated that its binding to $\mathrm{p} 75^{\mathrm{NTR}}$ was inhibited equally and completely by all neurotrophins. In addition, binding to trkA was substantially blocked by NT3, somewhat less by NT4/5, and not by BDNF (Fig. 3).

\section{NT3 receptors on cultured E11 sympathetic neurons}

Because the above results indicate that $\mathrm{p} 75^{\mathrm{NTR}}$ is a major component of NT3 high-affinity specific binding, it was of interest to perform similar cross-linking experiments with cultured neurons; the expression levels of $t r k C$ mRNA are negligible compared with intact sympathetic chains (Fig. 1). Sympathetic neurons were cultured for $4 \mathrm{~d}$ in the presence of NGF, and cross-linking experiments was performed with ${ }^{125} \mathrm{I}-\mathrm{NT} 3$ as above. Major bands

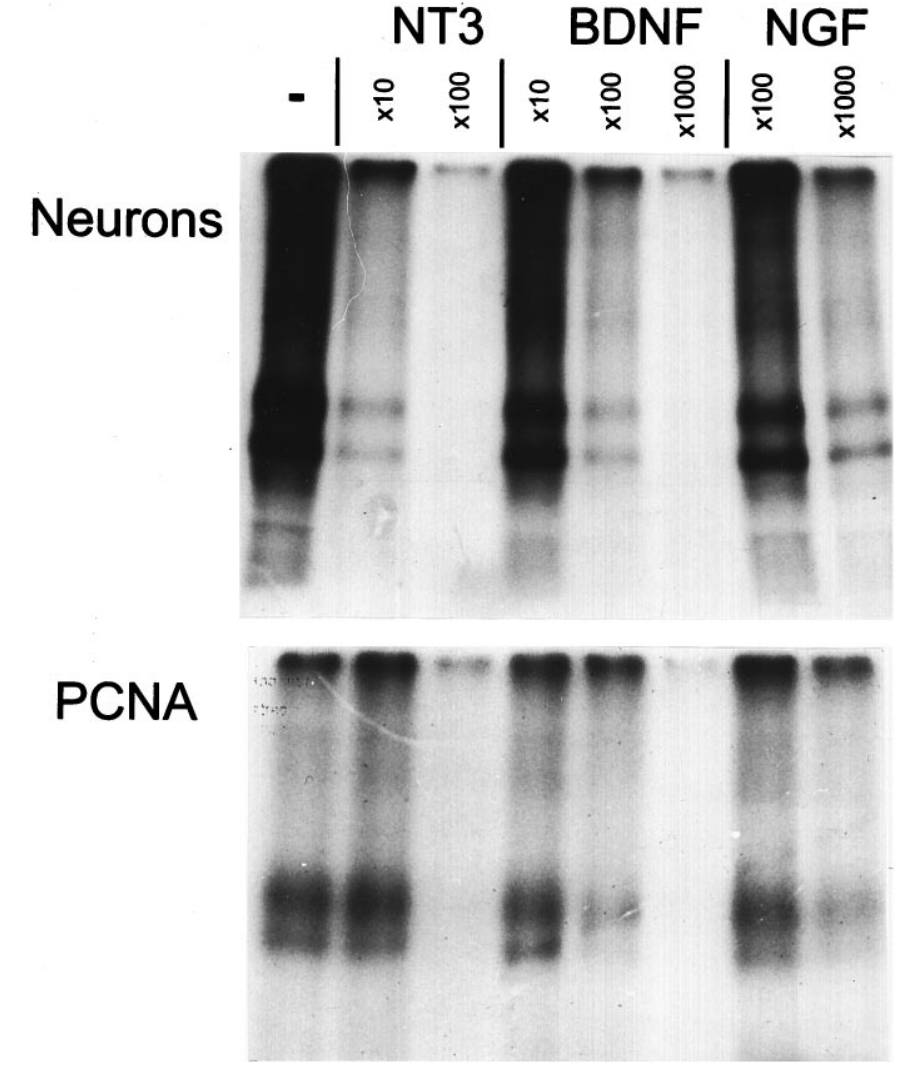

Figure 4. Chemical cross-linking of NT3 to E11 sympathetic cultures and PCNA cells. Neurons were cultured in the presence of NGF for $4 \mathrm{~d}$. The cultures were incubated with $3 \times 10^{-11}$ M radioiodinated NT3 (-), and the binding of the radioactive ligand was chased by a 10- to 1000 -fold molar excess of unlabeled neurotrophins NT3, BDNF, or NGF (top). These results are compared with an identical experiment with PCNA cells, a fibroblastic cell line overexpressing the $p 75^{\mathrm{NTR}}$ gene in the absence of endogenous neurotrophin binding sites (bottom).

of 60 and $80 \mathrm{kDa}$ were observed (Fig. 4), whereas the NT3-trkC complex could not be detected. A weak high molecular weight complex of $\sim 210 \mathrm{kDa}$ was also observed, which corresponds to the previously reported dimeric form of $\mathrm{p} 75^{\mathrm{NTR}}$ (Jing et al., 1992). Competition experiments indicate that as with freshly dissociated sympathetic neurons, unlabeled NT3 is a much better competitor for binding to $\mathrm{p} 75^{\mathrm{NTR}}$ compared with BDNF and NGF. The ability of p75 NTR to selectively bind NT3 is thus a property that can be observed in the absence of detectable crosslinking to trkC (Fig. 4). When similar experiments were performed with the fibroblastic cell line PCNA overexpressing p $75^{\text {NTR }}$ receptors, identical band patterns were observed $(60,80$, and $210 \mathrm{kDa}$ ), but prevention of binding by BDNF, NGF, or NT3 was roughly equally efficient (Fig. 4). Binding of ${ }^{125} \mathrm{I}-\mathrm{NT} 3$ to p $75^{\text {NTR }}$ on sympathetic neurons but not PCNA cells was already massively reduced at a 10-fold excess of unlabeled NT3. These cross-linking experiments thus reveal that on cultured sympathetic neurons, $\mathrm{p} 75^{\mathrm{NTR}}$ is the only detectable receptor for NT3 and its binds NT3 at very low concentrations and with high ligand specificity.

\section{Binding experiments with E11 sympathetic neuronal cultures}

To obtain quantitative information, binding experiments were then performed with cultured neurons. In steady-state binding 

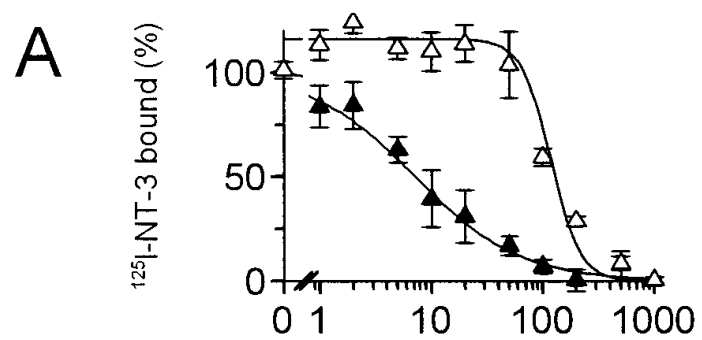

B
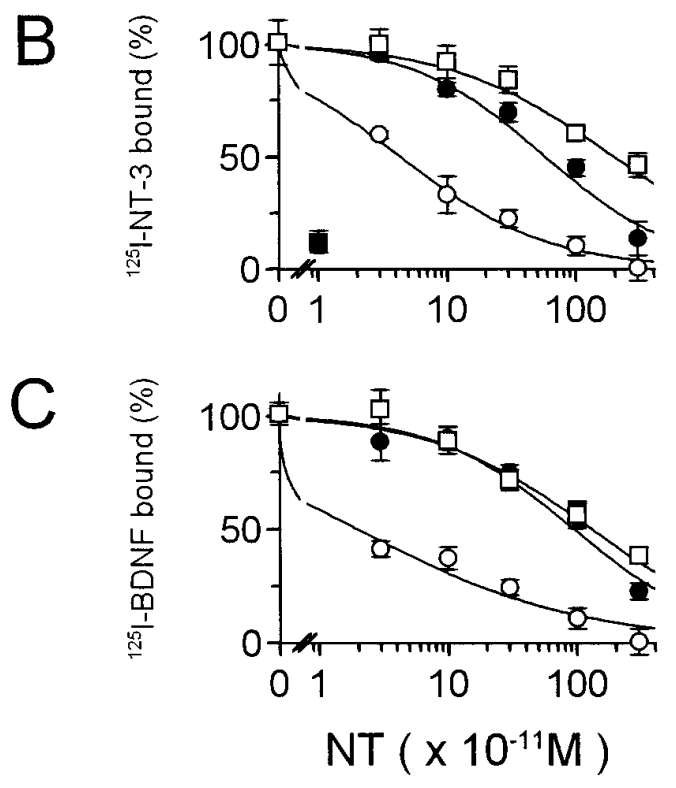

Figure 5. Inhibition of binding of ${ }^{125} \mathrm{I}-\mathrm{NT} 3$ and ${ }^{125} \mathrm{I}$-BDNF to neurons and PCNA cells under equilibrium conditions. The E11 sympathetic neuronal cultures for these experiments were grown in the presence of NGF for $4 \mathrm{~d}$. Under these conditions, $>90 \%$ of the specific binding can be blocked by Chex anti-p75 ${ }^{\text {NTR }}$ antiserum at $1: 1000$ dilution $(\boldsymbol{\square}$ in $B$ ). $A$, Binding of ${ }^{125} \mathrm{I}-\mathrm{NT} 3\left(3 \times 10^{-11} \mathrm{M}\right)$ to sympathetic neurons $(\boldsymbol{\Delta})$ or PCNA cells $(\triangle)$ inhibited by increasing concentrations of unlabeled NT3. $B$, Inhibition of binding of ${ }^{125} \mathrm{I}-\mathrm{NT} 3\left(3 \times 10^{-11} \mathrm{M}\right)$ to sympathetic neuronal cultures by NT3 $(\bigcirc)$, BDNF $(\bullet)$, or NGF $(\square)$. C, Inhibition of binding of ${ }^{125}$ I-BDNF $\left(3 \times 10^{-11} \mathrm{M}\right)$ to sympathetic neuronal cultures by NT3 $(\bigcirc)$, $\operatorname{BDNF}(\bullet)$, or NGF $(\square)$.

experiments, we found that cultured E11 sympathetic neurons express $4.5 \pm 1.5 \times 10^{4} \mathrm{NT} 3$ binding sites/cell binding with a $K_{\mathrm{d}}$ of $6 \pm 2 \times 10^{-11} \mathrm{M}$ (data not shown). This affinity is similar to that observed previously for NT3 high-affinity binding sites on both sensory and sympathetic neurons $\left(1-3 \times 10^{-11} \mathrm{M}\right)$. P75 ${ }^{\text {NTR }}$ accounts for most of this binding, because incubation of the cultured cells with the anti-p75 ${ }^{\text {NTR }}$ antiserum (1:1000) blocked $92 \pm 4 \%$ of the specific binding of ${ }^{125}$ I-NT3 to cultures of E11 sympathetic neurons (Fig. 5B). This reduction is less pronounced ( $\sim 50 \%$; data not shown) when the experiment is performed with freshly isolated neurons, in line with the cross-linking data indicating an involvement of trkC when binding components are analyzed on these neurons (Fig. 2). The unique binding characteristics of $\mathrm{p} 75^{\mathrm{NTR}}$ on cultured cells were then quantified and compared with those of $\mathrm{p} 75^{\mathrm{NTR}}$ expressed on PCNA cells (Fig. $5 A$ ). With unlabeled NT3, $50 \%$ inhibition of binding of radiolabeled NT3 (used at $3 \times 10^{-11} \mathrm{M}$ ) was observed at $8 \times 10^{-11} \mathrm{M}$ for sympathetic neurons and at $1.2 \times 10^{-9} \mathrm{M}$ with PCNA cells, reflecting the higher degree of receptor occupancy on sympathetic neurons. With cultured sympathetic neurons, ${ }^{125} \mathrm{I}-\mathrm{NT} 3$ binding was blocked by BDNF with an $\mathrm{IC}_{50}$ of $6 \times 10^{-10} \mathrm{M}$ and $2.5 \times 10^{-9}$ M for NGF (Fig. $5 B$ ). BDNF binds to p $75^{\text {NTR }}$ on E11 sympathetic neurons. At a concentration of $3 \times 10^{-11} \mathrm{M}$, specific binding of ${ }^{125} \mathrm{I}-\mathrm{BDNF}$ was markedly reduced compared with ${ }^{125} \mathrm{I}-\mathrm{NT} 3$, consistent with the lower affinity of BDNF and a correspondingly lower occupancy of $\mathrm{p} 75^{\mathrm{NTR}}$. NT3 very efficiently inhibited binding of ${ }^{125} \mathrm{I}-\mathrm{BDNF}$ to $\mathrm{p} 75^{\mathrm{NTR}}\left(\mathrm{IC}_{50}=3 \times 10^{-11} \mathrm{M}\right)$, in comparison with $\mathrm{BDNF}\left(\mathrm{IC}_{50}=1 \times 10^{-9} \mathrm{M}\right)$ and $\mathrm{NGF}\left(\mathrm{IC}_{50}\right.$ $\left.=3 \times 10^{-9} \mathrm{M}\right)($ Fig. $5 C)$. This result also indicates that highaffinity specific binding of NT3 for neuronal $p 75^{\text {NTR }}$ is independent of the use of radiolabeled NT3.

\section{DISCUSSION}

The characterization of the binding affinity of neurotrophin receptors on neurons has been useful, in particular with regard to neurotrophin responsiveness and selectivity of binding (for review, see Dechant et al., 1994). In this context, the NT3 binding sites described previously on E11 chick sympathetic neurons are intriguing because they display traditional characteristics of high affinity and selectivity, but their occupancy does not induce survival (Dechant et al., 1993b). The present study reveals that p $75^{\text {NTR }}$ is the molecule explaining the high-affinity selective binding of NT3 to these neurons and their processes.

\section{Neuronal $\mathrm{p} 75^{\mathrm{NTR}}$ forms high-affinity selective NT3 receptors}

The evidence identifying $\mathrm{p} 75^{\mathrm{NTR}}$ as the high-affinity receptor on sympathetic neurons comes from cross-linking experiments performed with radioiodinated NT-3 at concentrations filling highaffinity but not low-affinity sites. Complexes of $\sim 60$ and $80 \mathrm{kDa}$ were detected, and identical bands were obtained with PCNA cells overexpressing the $p 75^{\mathrm{NTR}}$ gene. These bands were undetectable in the presence of antibodies blocking the binding of neurotrophins to p $75^{\mathrm{NTR}}$, and binding of NT3 to the 60 and 80 $\mathrm{kDa}$ components was inhibited by all four neurotrophins, albeit only at high concentrations of NGF and BDNF. In contrast, NT4/5 can also bind efficiently to the NT3 high-affinity sites (Fig. 3 ), in line with previous studies using neurotrophin mutants (Rydén et al., 1995) and retrograde transport in vivo (Curtis et al., 1995), indicating a selective interaction of NT4/5 with $\mathrm{p} 75^{\mathrm{NTR}}$.

A $K_{\mathrm{d}}$ of $6 \times 10^{-11} \mathrm{M}$ was determined for the interaction of ${ }^{125} \mathrm{I}-\mathrm{NT} 3$ with $\mathrm{p} 75^{\mathrm{NTR}}$. This value is similar to the affinities of the NT3 high-affinity receptors on other neuronal populations (Rodríguez-Tébar et al., 1992) and for a proportion of the sites formed by recombinant trkC-expressing cell lines (Tsoulfas et al., 1993). trkC was not detectable in cultured neurons, however, indicating that this receptor cannot play a significant role in p $75^{\text {NTR }}$ high-affinity binding, which therefore seems to be independent of the formation of a ternary complex with trkC. Also, trkC protein is not very abundant on rodent sympathetic neurons (Belliveau et al., 1997). Because sympathetic neurons form an extensive network of processes in culture, it is likely that much of the NT3 binding occurs on nerve fibers, with a negligible contribution of the cell bodies. Finally, experiments with ${ }^{125} \mathrm{I}$-BDNF in which NT3 very efficiently inhibited binding to $\mathrm{p} 75^{\mathrm{NTR}}\left(\mathrm{IC}_{50}\right.$ of $3 \times 10^{-11} \mathrm{M}$ ) confirmed that high-affinity binding is also observed with unlabeled NT3.

\section{P75 ${ }^{\text {NTR }}$ on neurons and transformed cells}

This study revealed that the cellular environment plays a crucial role in determining the characteristics of the interactions between $\mathrm{NT3}$ and $\mathrm{p} 75^{\mathrm{NTR}}$. Consistent with previous results (RodríguezTébar et al., 1992), high-affinity binding of NT3 to p75 ${ }^{\mathrm{NTR}}$ was 
not obtained with PCNA cells (Figs. 4, 5). Interestingly, the differences in the binding properties of $\mathrm{p} 75^{\mathrm{NTR}}$ between neurons and PCNA cells were observed only with NT3 and not with NGF or BDNF. The high-affinity binding of NT3 to p $75^{\mathrm{NTR}}$ is unlikely to be restricted to sympathetic neurons. In a previous study, approximately 10-fold higher numbers of high-affinity NT3 receptors were observed on embryonic chick DRG neurons, compared with BDNF or NGF (Rodríguez-Tébar et al., 1992). We think that $\mathrm{p} 75^{\mathrm{NTR}}$ is likely to be a major contributor of highaffinity NT3 binding on these sensory neurons as well, because they express low levels of trkC (Williams et al., 1993). Also, we observed high-affinity binding of ${ }^{125}$ I-NT3 to suspensions of rat Schwann cells isolated from newborn sciatic nerves (data not shown), suggesting the existence of such p $75^{\text {NTR }}$ high-affinity NT3 receptors on various nontransformed cells.

How can the cellular context modify the binding characteristics of $\mathrm{p} 75^{\mathrm{NTR}}$ ? The allosteric model for neurotrophin $-\mathrm{p} 75^{\mathrm{NTR}}$ interactions offers an attractive framework (for discussion, see Bothwell, 1995). Indeed, as with other neurotrophins, positive cooperativity has been observed on binding of NT3 to p75 NTR (Rodríguez-Tébar et al., 1992), indicating that $\mathrm{p} 75^{\mathrm{NTR}}$ exists in (at least) two conformations with different ligand affinities. Consistent with this model, in addition to high-affinity binding sites for NGF and NT3, sympathetic neurons also express p75 NTR low-affinity binding sites for all neurotrophins (Godfrey and Shooter, 1986; Rodriguez-Tébar and Barde, 1988) (our unpublished results). Our results with sympathetic neurons could be explained by a modulation of the ratio between high- and lowaffinity forms of $\mathrm{p} 75^{\mathrm{NTR}}$, driven by hitherto unknown molecules in nontransformed cells. The absence of NGF or BDNF highaffinity binding to $\mathrm{p} 75^{\mathrm{NTR}}$ in our experiments indicates that sympathetic neurons do not equally induce the formation of high-affinity $\mathrm{p} 75^{\text {NTR }}$ binding sites for all neurotrophins. Previous studies with NT3 mutant proteins revealed that several amino acid residues in this neurotrophin contribute to the binding to p75 ${ }^{\text {NTR }}$, in particular R114 and K115 (Urfer et al., 1994) as well as Arg31 and His33 (Rydén et al., 1995). Therefore it is conceivable that NT3 contains more than one binding epitope with high and low affinities for $\mathrm{p} 75^{\mathrm{NTR}}$. Cell type-specific differences in the conformation of $\mathrm{p} 75^{\mathrm{NTR}}$ might determine which of these binding sites is used. Noteworthy are previous observations indicating that the binding properties of $\mathrm{p} 75^{\mathrm{NTR}}$ are sensitive to receptor aggregation. Thus, a shift in the affinity of $\mathrm{p} 75^{\mathrm{NTR}}$ for NGF was observed in the presence of wheat germ agglutinin, NGF antibodies, or the p $75^{\text {NTR }}$ monoclonal antibody 192 (Buxser et al., 1983; Grob et al., 1983; Vale and Shooter, 1983; Chandler et al., 1984). Also, aggregation by these agents can stimulate the association of p75 NTR to the cytoskeleton (Vale and Shooter, 1982, 1983; Vale et al., 1985). Although the molecular nature of this association is not clear, it is interesting to note that the $\mathrm{C}$ terminus of $\mathrm{p} 75^{\mathrm{NTR}}$ contains the critical residues mediating the interaction of various ion channels with the postsynaptic density protein PSD95 (Kornau et al., 1995). Finally, p75 NTR molecules carrying a 55 amino acid deletion in the intracellular domain are profoundly affected in cellular sorting, ligand internalization, signaling capacities, and lateral mobility in the membrane (Le Bivic et al., 1991; Dobrowsky et al., 1995; Wolf et al., 1995). The same mutants also have altered binding properties (Hempstead et al., 1990), indicating a role of the intracellular domain in the determination of ligand affinity. In our cross-linking experiments, we did not obtain direct evidence for NT3-driven receptor clustering; the ratio between monomeric and dimeric forms of cross- linked $\mathrm{p} 75^{\mathrm{NTR}}$ was not overtly changing in correlation to the ligand concentration (data not shown).

At present, the functional consequences of the formation of high-affinity and specific NT3 binding sites are unclear. An efficient removal or ligand neutralization system has already been suggested (Dechant et al., 1993b), but other possibilities exist. The recent and unexpected realization that NGF can uniquely activate $\mathrm{p} 75^{\mathrm{NTR}}$ invites caution in suggesting simplistic functions for the NT3/p75 ${ }^{\text {NTR }}$ sites on neurons (Carter et al., 1996; Frade et al., 1996).

In conclusion, our data indicate that $\mathrm{p} 75^{\mathrm{NTR}}$ can display remarkable properties of specificity on sympathetic neurons that are not observed when this molecule is expressed in transformed cells. This suggests that molecules profoundly modifying the properties of $\mathrm{p} 75^{\mathrm{NTR}}$ exist that are not ubiquitously expressed. In future studies, it will be interesting to determine the nature of the molecules in sympathetic neurons or other nontransformed cells that modify the properties of $\mathrm{p} 75^{\mathrm{NTR}}$.

\section{REFERENCES}

Barker PA, Shooter EM (1994) Disruption of NGF binding to the low affinity neurotrophin receptor $\mathrm{p} 75^{\mathrm{LNTR}}$ reduces NGF binding to TrkA on PC12 cells. Neuron 13:203-215.

Belliveau DJ, Krivko I, Kohn J, Lachance C, Pozniak C, Rusakov D, Kaplan D, Miller FD (1997) NGF and neurotrophin-3 both activate trkA on sympathetic neurons but differentially regulate survival and neuritogenesis. J Cell Biol 136:375-388.

Benedetti M, Levi A, Chao MV (1993) Differential expression of nerve growth factor receptors leads to altered binding affinity and neurotrophin responsiveness. Proc Natl Acad Sci USA 90:7859-7863.

Bothwell M (1995) Functional interactions of neurotrophins and neurotrophin receptors. Annu Rev Neurosci 18:223-253.

Buxser SE, Kelleher DJ, Watson L, Puma P, Johnson GL (1983) Change of state of nerve growth factor receptor: modulation of receptor affinity by wheat germ agglutinin. J Biol Chem 258:3741-3749.

Carter BD, Kaltschmidt C, Kaltschmidt B, Offenhäuser N, BöhmMatthaei R, Baeuerle PA, Barde YA (1996) Selective activation of NF-kappaB by nerve growth factor through the neurotrophin receptor p75. Science 272:542-545.

Chandler CE, Parsons LM, Hosang M, Shooter EM (1984) A monoclonal antibody modulates the interaction of nerve growth factor with PC12 cells. J Biol Chem 259:6882-6889.

Chao MV, Bothwell MA, Ross AH, Koprowski H, Lanahan AA, Buck CR, Sehgal A (1986) Gene transfer and molecular cloning of the human NGF receptor. Science 232:518-521.

Curtis R, Adryan KM, Stark JL, Park JS, Compton DL, Weskamp G, Huber LJ, Chao MV, Jaenisch R, Lee KF, Lindsay RM, DiStefano PS (1995) Differential role of the low affinity neurotrophin receptor (p75) in retrograde axonal transport of the neurotrophins. Neuron 14:1201-1211.

Davies AM, Lee K-F, Jaenisch R (1993) p75-deficient trigeminal sensory neurons have an altered response to NGF but not to other neurotrophins. Neuron 11:565-574.

Davies AM, Minichiello L, Klein R (1995) Developmental changes in NT3 signalling via TrkA and TrkB in embryonic neurons. EMBO J 14:4482-4489.

Dechant G, Biffo S, Okazawa H, Kolbeck R, Pottgiesser J, Barde Y-A (1993a) Expression and binding characteristics of the BDNF receptor chick trkB. Development 119:545-558.

Dechant G, Rodríguez-Tébar A, Kolbeck R, Barde Y-A (1993b) Specific high affinity receptors for neurotrophin-3 on sympathetic neurons. J Neurosci 13:2610-2616.

Dechant G, Rodríguez-Tébar A, Barde Y-A (1994) Neurotrophin receptors. Prog Neurobiol 42:347-352.

Dobrowsky RT, Jenkins GM, Hannun YA (1995) Neurotrophins induce sphingomyelin hydrolysis: modulation by co-expression of $\mathrm{p} 75^{\mathrm{NTR}}$ with Trk receptors. J Biol Chem 270:22135-22142.

Escandón E, Burton LE, Szönyi E, Nikolics K (1993) Characterization of neurotrophin receptors by affinity crosslinking. J Neurosci Res 34:601-613.

Escandón E, Soppet D, Rosenthal A, Mendoza-Ramírez J-L, Szönyi E, 
Burton LE, Henderson CE, Parada LF, Nikolics K (1994) Regulation of neurotrophin receptor expression during embryonic and postnatal development. J Neurosci 14:2054-2068.

Frade JM, Rodríguez-Tébar A, Barde YA (1996) Induction of cell death by endogenous nerve growth factor through its p75 receptor. Nature 383:166-168.

Garner AS, Large TH (1994) Isoforms of the avian TrkC receptor: a novel kinase insertion dissociates transformation and process outgrowth from survival. Neuron 13:457-472.

Godfrey EW, Shooter EM (1986) Nerve growth factor receptors on chick embryo sympathetic ganglion cells: binding characteristics and development. J Neurosci 6:2543-2550.

Götz R, Kolbeck R, Lottspeich F, Barde Y-A (1992) Production and characterization of recombinant mouse neurotrophin-3. Eur J Biochem 204:745-749.

Grob PM, Berlot CH, Bothwell MA (1983) Affinity labeling and partial purification of nerve growth factor receptors from rat pheochromocytoma and human melanoma cells. Proc Natl Acad Sci USA 80:6819-6823.

Hamburger V, Hamilton HL (1951) A series of normal stages in the development of the chick embryo. J Morphol 88:49-92.

Hempstead BL, Patil N, Thiel B, Chao MV (1990) Deletion of cytoplasmic sequences of the nerve growth factor receptor leads to loss of high affinity ligand binding. J Biol Chem 265:9595-9598.

Hempstead BL, Martin-Zanca D, Kaplan DR, Parada LF, Chao MV (1991) High-affinity NGF binding requires coexpression of the trk proto-oncogene and the low-affinity NGF receptor. Nature 350:678-683.

Jing S, Tapley P, Barbacid M (1992) Nerve growth factor mediates signal transduction through trk homodimer receptors. Neuron 9:1067-1079.

Kornau HC, Schenker LT, Kennedy MB, Seeburg PH (1995) Domain interaction between NMDA receptor subunits and the postsynaptic density protein PSD-95. Science 269:1737-1740.

Large TH, Weskamp G, Helder JC, Radeke MJ, Misko TP, Shooter EM, Reichardt LF (1989) Structure and developmental expression of the nerve growth factor receptor in the chicken central nervous system. Neuron 2:1123-1134.

Le Bivic A, Sambuy Y, Patzak A, Patil N, Chao M, Rodriguez-Boulan E (1991) An internal deletion in the cytoplasmic tail reverses the apical localization of human NGF receptor in transfected MDCK cells. J Biol Chem 115:607-618.

Lee K-F, Davies AM, Jaenisch R (1994) p75-deficient embryonic dorsal root sensory and neonatal sympathetic neurons display a decreased sensitivity to NGF. Development 120:1027-1033.

Lewin GR, Barde YA (1996) Physiology of the neurotrophins. Annu Rev Neurosci 19:289-317.

Palm SL, Furcht LT (1983) Production of laminin and fibronectin by Schwannoma cells: cell-protein interactions in vitro and protein localization in peripheral nerve in vivo. J Cell Biol 96:1218-1226.

Radeke MJ, Misko TP, Hsu C, Herzenberg LA, Shooter EM (1987) Gene transfer and molecular cloning of the rat nerve growth factor receptor: a new class of receptors. Nature 325:593-597.
Rodriguez-Tébar A, Barde Y-A (1988) Binding characteristics of brainderived neurotrophic factor to its receptors on neurons from the chick embryo. J Neurosci 8:3337-3342.

Rodriguez-Tébar A, Rohrer H (1991) Retinoic acid induces NGFdependent survival response and high-affinity NGF receptors in immature chick sympathetic neurons. Development 112:813-820.

Rodríguez-Tébar A, Dechant G, Götz R, Barde Y-A (1992) Binding of neurotrophin-3 to its neuronal receptors and interactions with nerve growth factor and brain-derived neurotrophic factor. EMBO J 11:917-922.

Rodríguez-Tébar A, De la Rosa EJ, Arribas A (1993) Neurotrophin-3 receptors in the developing chicken retina. Eur J Biochem 211:789-794.

Rydén M, Murray-Rust J, Glass D, Ilag LL, Trupp M, Yancopoulos GD, McDonald NQ, Ibáñez CF (1995) Functional analysis of mutant neurotrophins deficient in low-affinity binding reveals a role for $\mathrm{p} 75^{\mathrm{LNGFR}}$ in NT-4 signalling. EMBO J 14:1979-1990.

Schröpel A, Von Schack D, Dechant G, Barde Y-A (1995) Early expression of the nerve growth factor receptor ctrkA in chick sympathetic and sensory ganglia. Mol Cell Neurosci 6:544-556.

Snider WD (1994) Functions of the neurotrophins during nervous system development: what the knockouts are teaching us. Cell 77:627-638.

Suda K, Barde Y-A, Thoenen H (1978) Nerve growth factor in mouse and rat serum: correlation between bioassay and radioimmunoassay determinations. Proc Natl Acad Sci USA 75:4042-4046.

Tsoulfas P, Soppet D, Escandon E, Tessarollo L, Mendoza-Ramirez J-L, Rosenthal A, Nikolics K, Parada LF (1993) The rat trkC locus encodes multiple neurogenic receptors that exhibit differential response to neurotrophin-3 in PC12 cells. Neuron 10:975-990.

Urfer R, Tsoulfas P, Soppet D, Escandón E, Parada LF, Presta LG (1994) The binding epitopes of neurotrophin-3 to its receptors trkC and gp75 and the design of a multifunctional human neurotrophin. EMBO J 13:5896-5909.

Vale RD, Shooter EM (1982) Alterations of binding properties and cytoskeletal attachment of nerve growth factor receptors in PC12 cells by wheat germ. J Cell Biol 94:710-717.

Vale RD, Shooter EM (1983) Conversion of nerve growth factorreceptor complexes to a slowly dissociating Triton X-100 insoluble state by anti-nerve growth factor antibodies. Biochemistry 22:5022-5028.

Vale RD, Ignatius MJ, Shooter EM (1985) Association of nerve growth factor receptors with the Triton X-100 cytoskeleton of PC12. J Neurosci 5:2762-2770.

Weskamp G, Reichardt LF (1991) Evidence that biological activity of NGF is mediated through a novel subclass of high affinity receptors. Neuron 6:649-663.

Williams R, Bäckström A, Ebendal T, Hallböök F (1993) Molecular cloning and cellular localization of trkC in the chicken embryo. Dev Brain Res 75:235-252.

Wolf DE, McKinnon CA, Daou M-C, Stephens RM, Kaplan DR, Ross AH (1995) Interaction with TrkA immobilizes gp 75 in the high affinity nerve growth factor receptor complex. J Biol Chem 270:2133-2138. 